\title{
MEMASYARAKATKAN MATEMATIKA MELALUI PERAN KELUARGA
}

\author{
Marhadi Saputro, Muhamad Firdaus, Yudi Darma, Rahman Haryadi, Hartono, Yadi \\ Ardiawan, Utin Desy Susiaty, Dwi Oktaviana, Wandra Irvandi \\ IKIP PGRI Pontianak \\ marhadi.mat09@gmail.com
}

\begin{abstract}
Abstrak: Kegiatan pengabdian kepada masyarakat ini berupa penyuluhan dengan judul "Memasyarakatkan Matematika Melalui Peran Keluarga". Kegiatan ini dilaksanakan di Aula Desa Batu Ampar. Peserta kegiatan PKM ini adalah orang tua siswa yang berdomisili di desa Batu Ampar, yang berjumlah 30 orang. Tujuan dari kegiatan pengabdian adalah untuk: (1) memberikan penyuluhan kepada masyarakat Kecamatan Batu Ampar Kabupaten Kubu Raya tentang memotivasi dan menumbuhkan minat terhadap matematika; (2) mengetahui tanggapan masyarakat terhadap penyuluhan tentang memasyarakatkan matematika. Kegiatan pengabdian kepada masyarakat yang berupa penyuluhan Memasyarakatkan Matematika Melalui Peran Keluarga di Batu Ampar ini dapat disimpulkan yaitu: (1) kegiatan penyuluhan memberikan informasi dan motivasi kepada orang tua selaku keluarga yang mempunyai peran penting dalam melakukan pendampingan belajar anak di rumah sebagai upaya meningkatkan kualitas pembelajaran khususnya mata pelajaran matematika anak; (2) kegiatan pelatihan ini perlu diadakan kembali untuk daerah yang lain sehingga dapat menambah pengetahuan dan informasi yang akurat kepada keluarga betapa pentingnya peran mereka sebagai pendamping belajar anak.
\end{abstract}

Kata kunci: Memasyaratkan, Matematika, Peran keluarga

\begin{abstract}
This community service program is in the form of counseling with the title "Socializing Mathematics through the Role of Families." This program was carried out in the Batu Ampar Village Hall. The participants are thirty parents of students who live in Batu Ampar village. The program aims to: (1) provide counseling to the people of Batu Ampar Subdistrict, Kubu Raya Regency about motivating and fostering interest in mathematics; (2) knowing the community's response to counseling about socializing mathematics. Community service activities in the form of counseling Socializing Mathematics through the Role of Families in Batu Ampar can be concluded, namely: (1) extension activities provide information and motivation to parents as families who have an important role in assisting child learning at home as an effort to improve the quality of learning especially children's mathematics subjects; (2) this training activity needs to be held again for other regions so that it can add accurate knowledge and information to the family how important their role is as a child learning companion.
\end{abstract}

Keywords: socialize, mathematic, family role

\section{Pendahuluan}

Tujuan pendidikan adalah untuk menciptakan pribadi-pribadi yang memiliki idealisme yang tinggi. Pribadi seperti itu berkewajiban menjadikan akhlak dan moral sebagai ikatan. Melalui pendidikan simpul-simpul norma dan nilai dapat ditegakkan, jika masing-masing pribadi mematuhi tata aturan dalam kehidupannya, melaksanakan norma-norma dalam masyarakat, dan memperbaiki pemahaman berdasarkan landasan yang benar. Inilah tugas berat yang harus dipikul bersama oleh semua komponen masyarakat.

Pusat pendidikan yang pertama adalah lingkungan keluarga, pendidikan di lingkungan keluarga sangat strategis untuk memberikan pendidikan ke arah kecerdasan, budi pekerti atau kepribadian serta persiapan hidup di masyarakat. Orang tua akan menjadi contoh bagi anak, 
anak biasanya akan menirukan apa saja yang dilakukan oleh orang tua. Jadi orang tua harus bisa memberikan keteladanan dan kebiasaan sehari-hari yang baik sehingga dapat dijadikan contoh bagi anaknya. Keteladanan dan kebiasaan yang baik itu, sebaiknya diberikan oleh orang tua sejak dari kecil karena hal itu dapat berpengaruh terhadap perkembangan jiwa anak.

Orang tua merupakan pendidik utama dan pertama bagi anak-anak mereka, karena dari merekalah anak mula-mula menerima pendidikan. Dengan demikian bentuk pertama pendidikan terdapat dalam kehidupan keluarga. ${ }^{1}$ Lingkungan rumah dan keluarga memiliki andil yang sangat besar dalam pembentukan perilaku anak. Untuk itu pastilah ada usaha yang harus dilakukan terutama oleh pihak-pihak yang terkait didalamnya sehingga mereka akan memiliki tanggung jawab dalam hal ini. ${ }^{2}$

Peranan lingkungan keluarga merupakan salah satu pilar dalam tri pusat pendidikan. Lingkungan keluarga adalah Pilar utama untuk membentuk baik buruknya pribadi manusia agar berkembang dengan baik dalam beretika, moral dan akhlaknya. Peran Keluarga dapat membentuk pola sikap dan pribadi anak, juga dapat menentukan proses pendidikan yang diperoleh anak, tidak hanya di sekolah akan tetapi semua faktor bisa dijadikan sumber pendidikan. Lingkungan keluarga juga dapat berperan menjadi sumber pengetahuan anak, juga dapat berpengaruh tehadap keberhasilan prestasi siswa.Anak dalam kandungan sampai usia lanjut atau liang lahat akan mendapatkan pendidikan, baik dari lingkungan keluarga (pendidikan informal), Lingkungan Sekolah (formal) maupun Lingkungan Masyarakat (nonformal). Lingkungan keluarga harus dapat memberikan dan menyiapkan pendidikan untuk anaknya agar menjadi generasi penerus yang terdidik, yakni melalui jenjang pendidikan sehingga terbentuk dan berkembang pribadi anak yang berkarakter baik, berjiwa sosial, bersikap yang beradab dan terampil dalam skillnya. ${ }^{3}$ Keluarga merupakan lingkungan pendidikan yang pertama, karena dalam keluarga anak pertama-tama mendapatkan didikan dan bimbingan. Juga dikatan lingkungan yang utama, karena sebagian besar dari kehidupan anak adalah di dalam keluarga, sehingga pendidikan yang paling banyak diterima oleh anak adalah dalam keluarga. ${ }^{4}$

Orang tua sebaiknya memperhatikan pendidikan anak-anaknya karena peran orang tua sangat penting dalam proses pendidikan bagi mereka. Anak-anak memiliki dunianya sendiri. Hal itu ditandai dengan banyaknya gerak, penuh semangat, suka bermain pada setiap tempat dan waktu, tidak mudah letih, dan cepat bosan. Anak-anak memiliki rasa ingin tahu yang besar dan selalu ingin mencoba segala hal yang dianggapnya baru, Anak-anak hidup dan berfikir untuk saat ini, sehingga ia tidak memikirkan masa lalu yang jauh dan tidak pula masa depan yang tidak diketahuinya. Oleh sebab itu, seharusnya orang tua dapat menjadikan realitas masa sekarang sebagai titik tolak dan metode pembelajaran bagi anak (Agustin, dkk., 2015:46). Orang tua mampu menyediakan kebutuhan materiil anak-anaknya secara memuaskan tetapi

${ }^{1}$ Raudhoh. 2017. Peran Keluarga dalam Pendidikan Anak Usia Dini. Jurnal Studi Gender dan Anak. Vol 2, no. 1. HIm: 83-108.

2 Subianto, J. 2013. Peran Keluarga, Sekolah dan Masyarakat dalam Pembentukan Karakter yang Berkualitas. Jurnal Penelitian Pendidikan Islam. Vol 8, no. 2. HIm: 331-354.

${ }^{3}$ Hulukati, W. 2015. Peran Lingkungan Keluarga terhadap Perkembangan Anak. MUSAWA. Vol 7, no. 2. HIm: 265-282.

${ }^{4}$ Hasbullah. 2005. Dasar-Dasar IImu Pendidikan. Jakarta: Raja Grafindo 
kebutuhan pendidikan tidak pernah terpenuhi. Anak tidak dipersiapkan menjadi manusia yang dewasa seperti tujuan yang hendak dicapai oleh pendidikan. Anak berkembang tanpa adanya pola yang hendak dituju, tetapi berkembang dengan sendirinya. Anak dibiarkan saja tumbuh tanpa tuntutan norma yang pasti. Tidak ada kepastian pada diri anak, bagaimana seharusnya ia berbuat atau bersikap karena memang tidak pernah diberi tahu dan dibimbing oleh orangtuanya. Situasi seperti ini disebut miss educated. Kadang-kadang hal demikian ini oleh orangtuanya tidak disadari, jadi tidak disengaja. Orang tua berbuat demikian mungkin karena tidak tahu, yaitu tidak tahu bagaimana mendidik anaknya dan tahu tetapi situasi memaksa demikian, mungkin karena terlalu sibuk. Oleh karena itu, untuk menjadi orang tua dituntut syarat-syarat tertentu agar anak-anaknya berkembang dengan baik. Jika suatu keluarga dikaruniai seorang anak, maka pada pundak orangtua itulah dibebankan usaha bagaimana agar anak-anaknya berkembang dengan baik. Jadi anak tidak diterima begitu saja, diberi makan dan pakaian tetapi diusahakan agar anak mampu berkembang dengan baik. Orang tua harus mampu membagi-bagi perhatiannya kepada semua obyek di dalam rumah tangganya sebab di dalam keluargalah terjadi interaksi orang tua terhadap anak. Kasih sayang yang diberikan orang tua pada awal kehidupan seorang anak sangat membantu perkembangan anak bahkan menjadi dasar peletakkan kepribadiannya.

Pentingnya peran orang tua terhadap pendidikan anak bukanlah hal yang sepele karena pendidikan adalah modal utama yang harus dimiliki oleh setiap individu yang hidup agar dapat bertahan menghadapi perkembangan zaman. Seperti saat ini orang tua semakin menyadari pentingnya memberikan pendidikan yang terbaik kepada anak-anak mereka sejak dini. Keterlibatan orang tua dalam pendidikan anak-anak terbukti memberikan banyak dampak positif bagi anak.

Orang tua di dalam keluarga dan lingkungan social masyarakat merupakan tempat belajar seorang anak untuk pertama kalinya. Oleh karena itu, seorang anak membutuhkan stimulasi yang tepat agar anak dapat tumbuh dan berkembang dengan optimal. Bloom menyatakan perkembangan intelegensi, kepribadian dan tingkah laku social berkembang pesat ketika anak berada pada masa usia dini. ${ }^{5}$ Pada masa itulah peran orangtua sangat dominan dalam meningkatkan pendidikan bagi anak usia dini.

Oleh karena itu orang tua harus lebih memperhatikan anak-anak mereka, melihat potensi dan bakat yang ada pada anak mereka, memberikan sarana dan prasarana untuk mendukung proses pembelajaran mereka di sekolah serta selalu memotivasi anak agar tetap semangat dalam belajar. Para orang tua juga diharapkan dapat melakukan semua itu dengan niat yang tulus untuk menciptakan generasi yang mempunyai moral yang baik dan wawasan yang tinggi serta semangat pantang menyerah.

Berdasarkan uraian di atas, dipertimbangkan perlu dilakukan penyuluhan dalam memasyarakatkan matematika melalui peran keluarga, yang karena keterbatasan waktu, dana, dan tenaga, dibatasi pada masyarakat di Kecamatan Batu Ampar Kabupaten Kubu Raya.

${ }^{5}$ Siskandar. 2003. Kurikulum Berbasis Kompetensi untuk Anak Usia Dini. Buletin PADU: Jurnal Ilmiah Anak Usia Dini. Vol 2: 21-22. 
Harapannya, setelah penyuluhan, keluarga menjadi lebih memantau perkembangan anaknya serta dapat membimbing anaknya dalam belajar.

\section{Metode}

Kegiatan PKM ini berupa penyuluhan dengan judul "Memasyarakatkan Matematika Melalui Peran Keluarga". Kegiatan ini dilaksanakan di Aula Desa Batu Ampar. Peserta kegiatan PKM ini adalah orang tua siswa yang berdomisili di desa Batu Ampar, yang berjumlah 30 orang. Pelaksanaan PKM kepada orang tua siswa yang berdomisili di desa Batu Ampar dilaksanakan pada tanggal 15 - 16 Agustus 2018. Khalayak sasaran kegiatan pengabdian masyarakat ini adalah masyarakat. Alasan pemilihan lokasi ini karena masyarakat mempunyai keinginan dalam memperoleh pengetahuan tentang memotivasi dan menumbuhkan minat anak terhadap matematika, namun pengetahuan tentang hal tersebut masih minim.

Metode yang digunakan dalam pelaksanaan kegiatan ini berupa penyuluhan, jadi kegiatan menggunakan metode ceramah oleh Bapak Wandra Irvandi, S.Pd, M.Sc, selaku narasumber dan disertai dengan tanya jawab. Hal ini dilakukan dengan harapan agar orang tua sebagai pendamping dalam proses belajar anak sebagai siswa memahami apa saja peran keluarga dalam upaya meningkatkan kualitas pembelajaran matematika anak. Metode yang digunakan dalam pelaksanaan kegiatan ini adalah sebagai berikut: (1) metode ceramah untuk memberikan penyuluhan tentang memotivasi dan menumbuhkan minat anak terhadap matematika; (2) metode diskusi untuk membahas tentang memotivasi dan menumbuhkan minat anak terhadap matematika.

Untuk melaksanakan penyuluhan ini dibutuhkan beberapa langkah mulai dari persiapan hingga evaluasi kegiatan. Adapun berbagai bentuk kegiatan yang akan dilaksanakan adalah sebagai berikut. (1) Persiapan kegiatan yang dilaksanakan oleh Tim PKM untuk merencanakan kegiatan pelatihan yang mencakup waktu, materi, dan teknis pelaksanaan kegiatan. (2) Pelaksanaan penyuluhan tentang memotivasi dan menumbuhkan minat anak terhadap matematika. (3) Evaluasi kegiatan secara umum oleh peserta PKM serta Tim PKM hingga selesainya laporan kegiatan.

\section{Hasil dan Pembahasan}

Kegiatan pelatihan penggunaan media ini dimulai dengan penyampaian materi tentang "Peran keluiarga dalam Upaya Meningkatkan Kualitas Pembelajaran Matematika Anak. Setelah penjelasan materi, dilanjutkan dengan tanya jawab peserta kepada narasumber.

Kegiatan dilanjutkan dengan sesi tanya jawab. Orang tua selaku individu yang paling berperan dalam perkembangan belajar anak banyak mengajukan pertanyaan. Respon positif dari para orang tua membuat narasumber bersemangat dalam menjawab pertanyaan. Hampir semua peserta bahkan menceritakan pengalaman pribadinya dalam hal memberikan bimbingan belajar kepada anak. 


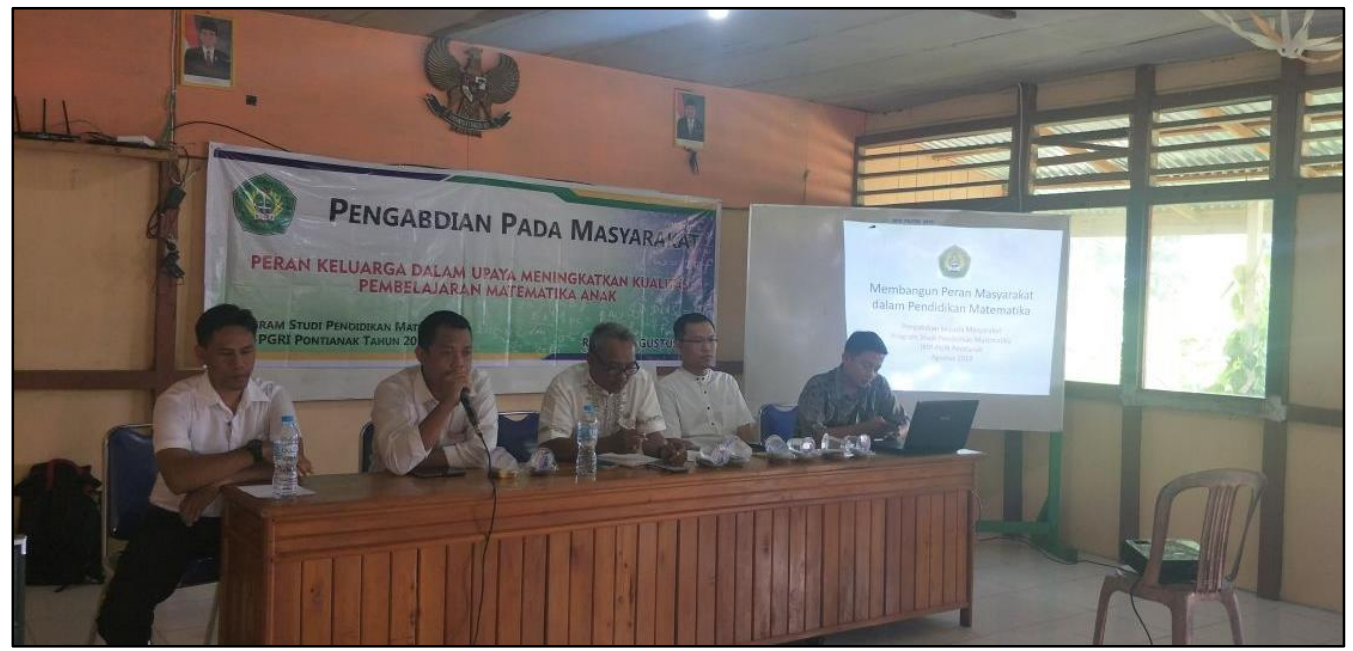

Gambar 1. Sesi Penyampaian Materi dan Tanya Jawab

Selanjutnya setelah penyuluhan selesai dilanjutkan sesi dokumentasi sebagai ajang keakraban dan kekeluargaan opleh pemateri, narasumber dan peserta Pengabdian Kepada Masyarakat.

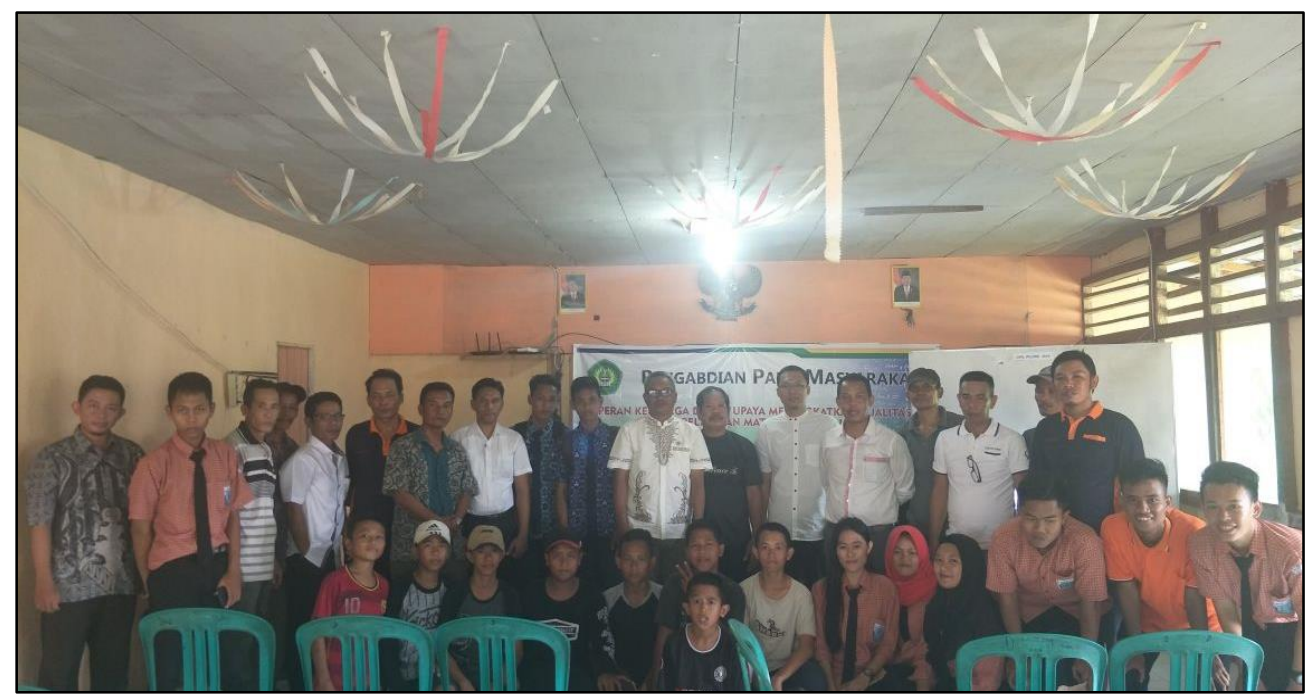

Gambar 2. Sesi Foto Bersama

Selanjutnya panitia Pengabdian Kepada Masyarakat memberikan angket pendampingan sebagai sesi terakhir dalam penyuluhan. Adapun angket yang diberikan disajikan pada table 1 berikut.

Tabel 1. Angket Pendampingan Belajar Anak oleh Orang Tua

1. Apakah ada anak usia sekolah di rumah anda?

a. Ada

b. Tidak

Jika ada, kelas berapa? (boleh lebih dari 1) 
2. Seberapa sering anak anda mendapatkan tugas (PR dari sekolah)?
a. Setiap hari
b. 3-4 hari perminggu
c. 1-2 hari perminggu
d. Tidak pernah

3. Siapa yang paling sering menemani anak mengerjakan tugas (PR dari sekolah)?
a. Ayah
b. Ibu
c. Kakak/abang
d. Keluarga yang lain/guru les

4. Pernahkah anak anda bertanya kepada anda mengenai PR dari sekolah?

a. Pernah

b. Tidak pernah

5. Apakah anda kesulitan dalam dalam membantu anak mengerjakan PRnya?

a. Ya

b. Tidak

6. Sebutkan Mata Pelajaran apa yang paling sulit ketika anak anda bertanya mengenai PRnya?

7. Apakah anda pernah bertanya atau memeriksa buku pelajaran anak anda dan melihat berapa nilai yang ia peroleh?
a. Ya
b. Tidak

8. Pernahkan anda memuji anak anda atas nilai (ulangan/latihan/pr/raport) yang ia peroleh?
a. Ya
b. Tidak

9. Pernahkan anda memarahi anak anda atas nilai yang ia peroleh?
a. Ya
b. Tidak

10. Seberapa besar anda ingin anak anda menyelesaikan sekolahnya ke jenjang Perguruan Tinggi?
a. Sangat ingin
b. Ingin
c. Biasa saja

Berdasarkan angket pada table 1 diperolehlah respon peserta penyuluhan terhadap pertanyaan angket nomor 1 yaitu "apakah ada anak usia sekolah di rumah anda?" mendapat respon sebesar $100 \%$ untuk option ada. Hal ini menunjukkan peserta penyuluhan semuanya mempunyai keluarga yang berada pada usia sekolah. Respon peserta penyuluhan terhadap pertanyaan angket nomor 2 yaitu "seberapa sering anak anda mendapatkan tugas (PR dari sekolah)?" mendapat respon 50\% untuk option setiap hari, 16,7\% untuk option 3-4 hari perminggu, 33,3\% untuk option 1-2 hari perminggu dan $0 \%$ untuk option tidak pernah. Hal ini menunjukkan bahwa sebagian besar anak dari peserta penyuluhan mendapatkan tugas dari sekolah hamper setiap hari.

Respon peserta untuk pertanyaan angket nomor 3 yaitu "siapa yang paling sering menemani anak mengerjakan PR dari sekolah?" Mendapat respon sebesar 16,7\% untuk option ayah, 66,7\% untuk option ibu, 8,3\% untuk option kakak/abang dan 8,3\% untuk option keluarga yang lain/guru les. Hal ini menunjukkan yang sangat berperan dalam proses pendampingan belajar anak adalah sang ibu dibandingkan dengan anggota keluarga yang lain. Respon peserta penyuluhan untuk pertanyaan angket nomor 4 yaitu "pernahkah anak anda bertanya kepada anda 
mengenai PR dari sekolah?" mendapat respon sebesar $91,7 \%$ untuk option pernah dan 8,3\% untuk option tidak pernah. Hal ini mengindikasikan bahwa hamper semua peserta penyuluhan pernah mendapatkan pertanyaan oleh sang anak seputar tugas sekolah dan ini juga menunjukkan bahwa anak sangat membutuhkan pendampingan dari keluarga terdekat dalam belajar.

Respon peserta penyuluhan untuk pertanyaan angket nomor 5 yaitu "apakah anda kesulitan dalam membantu anak mengerjakan PR nya?" mendapat respon sebesar 58,3\% untuk option ya dan $41,7 \%$ untuk option tidak. Hal ini mengindikasikan bahwa sebagain besar orang tua mengalami kesulitan dalam pendampingan belajar anaknya. Respon peserta penyuluhan untuk pertanyaan angket nomor 6 yaitu "sebutkan mata pelajaran apa yang paling sulit ketika anak anda bertanya mengenai PR nya?" mendapat respon sebesar $75 \%$ untuk option matematika, 8,3\% untuk option sosiologi dan 16,7\% untuk option Bahasa inggris. Hal ini mengindikasi bahwa hamper lebih dari separuh peserta penyuluhan sebagai orang tua mengalami kesulitan pendampingan belajar anak khususnya pada mata pelajaran matematika.

Respon peserta penyuluhan untuk pertanyaan angket nomor 7 yaitu "apakah anda pernah bertanya atau memeriksa buku pelajaran anak anda dan melihat berapa nilai yang ia peroleh?" mendapat respon sebesar $100 \%$ untuk option ya. Hal ini menunjukkan seluruh peserta penyuluhan selalu melaksanakan pendampingan belajar anak walaupun kadang ada kesulitan dalam menjawab pertanyaan dari tugas belajar yang diberikan. Respon peserta penyuluhan untuk pertanyaan angkat nomor 8 yaitu "pernahkah anda memuji anak anda atas nilai (ulangan/latihan/pr/raport) yang ia peroleh?" mendapat respon sebesar $66,7 \%$ untuk option ya dan 33,3\% untuk option tidak. Hal ini mengindikasikan bahwa sebagian besar peserta memberikan penghargaan kepada anak sebagai proses dalam pendampingan belajar anak sehingga anak menjadi termotivasi untuk meningkatkan kompetensi belajarnya.

Respon peserta penyuluhan untuk pertanyaan angket nomor 9 yaitu "pernahkah anda memarahi anak anda atas nilai yang ia peroleh?" mendapat respon sebesar $75 \%$ untuk option ya dan $25 \%$ untuk option tidak. Hal ini menunjukkan bahwa tingkat kesabaran peserta penyuluhan sebagai orang tua yang berperan dalam pendampingan belajar anak sangat kurang. Respon peserta penyuluhan untuk pertanyaan angket nomor 10 yaitu "seberapa besar anda ingin anak anda menyelesaikan sekolahnya hingga ke jenjang perguruan tinggi?" mendapat respon sebesar $100 \%$ untuk option sangat ingin. Hal ini mengindikasi bahwa seluruh anak peserta penyuluhan mempunyai keinginan yang kuat dalam melanjutkan pendidikannya ke jenjang yang lebih tinggi. Hal ini seharusnya mendapatkan dukungan dari orang tua dan peran keluarga khusunya dalam bentuk pendampingan belajar anak dalam upaya mengingkatkan kualitas pembelajaran si anak.

Kegiatan dilaksanakan pada tanggal 15 - 16 Agustus 2018 dengan rincian sebagai berikut.

Tabel 2. Jadwal Kegiatan PKM

\begin{tabular}{lll}
\hline Waktu & \multicolumn{1}{c}{ Materi } & Penyaji \\
\hline $08.00-09.00$ & Pembukaan & Panitia \\
$09.00-10.30$ & Motivasi Dan Minat Terhadap & Wandra Irvandi, S.Pd, M.Sc \\
& Matematika & \\
$10.30-12.00$ & Pendidikan Matematika & Rahman Haryadi, M.Pd \\
$12.00-12.30$ & Penutup & Panitia \\
\hline
\end{tabular}




\section{Kesimpulan}

Kegiatan pengabdian kepada masyarakat yang berupa penyuluhan Memasyarakatkan Matematika Melalui Peran Keluarga di Batu Ampar ini dapat disimpulkan yaitu: (1) kegiatan penyuluhan memberikan informasi dan motivasi kepada orang tua selaku keluarga yang mempunyai peran penting dalam melakukan pendampingan belajar anak di rumah sebagai upaya meningkatkan kualitas pembelajaran khususnya mata pelajaran matematika anak; (2) tanggapan/respon masyarakat terhadap kegiatan pelatihan ini adalah masyarakat memandang perlu diadakan kembali untuk daerah yang lain sehingga dapat menambah pengetahuan dan informasi yang akurat kepada keluarga betapa pentingnya peran mereka sebagai pendamping belajar anak.

\section{Ucapan Terima Kasih}

Terima kasih diucapkan kepada IKIP PGRI Pontianak atas dana Pengabdian kepada Masyarakat tahun anggaran 2018 yang diberikan dan pejabat serta masyarakat Desa Batu Ampar Kubu Raya sebagai mitra dalam kegiatan pengabdian.

\section{Referensi}

LPKM. 2017. Buku Panduan Pelaksanaan Pengabdian Kepada Masyarakat IKIP PGRI Pontianak. Pontianak: LPKM.

Siskandar. 2003. Kurikulum Berbasis Kompetensi untuk Anak Usia Dini. Buletin PADU: Jurnal IImiah Anak Usia Dini. Vol 2: 21-22.

Hasbullah. 2005. Dasar-Dasar IImu Pendidikan. Jakarta: Raja Grafindo

Raudhoh. 2017. Peran Keluarga dalam Pendidikan Anak Usia Dini. Jurnal Studi Gender dan Anak. Vol 2, no. 1. HIm: 83-108.

Subianto, J. 2013. Peran Keluarga, Sekolah dan Masyarakat dalam Pembentukan Karakter yang Berkualitas. Jurnal Penelitian Pendidikan Islam. Vol 8, no. 2. HIm: 331-354.

Hulukati, W. 2015. Peran Lingkungan Keluarga terhadap Perkembangan Anak. MUSAWA. 7 (2): 265282.

Agustin, D.S.Y., Suarmini, N.W., \& Prabowo, S. 2015. Peran Keluarga Sangat Penting dalam Pendidikan Mental, Karakter Anak serta Budi Pekerti Anak. Jurnal Sosial Humaniora. 8 (1): 4654. 